\title{
Comparative Study of Blood Metal Levels in Post-Mortem and Living Population Samples from Dammam, KSA
}

\author{
Ahmed R Ragab ${ }^{1,2 *}$, Maha K Al-Mazroua ${ }^{2}$, Sahar M Younis ${ }^{2,3}$, Ahmed Al-Emam ${ }^{1,4}$, Nadia M Al-Moagel' ${ }^{2}$ Ansam Y Al-Buaijan² and Aqueel M \\ Al-Abadie ${ }^{2}$
}

${ }^{1}$ Department of Forensic Medicine and Clinical Toxicology, Faculty of Medicine, Mansoura University, Egypt ${ }^{2}$ Dammam Poison Control Center, Dammam, Eastern Region, Ministry of Health, Saudi Arabia

${ }^{3}$ Department of Forensic Medicine and Clinical Toxicology, Faculty of Medicine, Al-Xenderia University, Egypt

${ }^{4}$ Department of Pathology, College of Medicine, King Khalid University, Saudi Arabia

\begin{abstract}
Post-mortem testing of drugs and toxic agents is becoming an increasingly indispensible part of the forensic pathology routine that has recently made considerable progress. However, little attention has been given to the post-mortem blood and tissue metal levels compared to reference values of living population. Therefore, this study was designed to determine the post-mortem blood levels of arsenic (As), selenium (Se), silver (Ag), cadmium (Cd), antimony $(\mathrm{Sb})$, mercury $(\mathrm{Hg})$, thallium $(\mathrm{Ti})$ and lead $(\mathrm{Pb})$ and to compare their levels with the measured reference values from a living population sample. Moreover, the relationship between the post-mortem blood metal levels and the post-mortem interval (PMI) was investigated. Two hundreds and twelve post-mortem femoral blood samples were collected from autopsied cases at the Forensic Medicine centre in Dammam Saudi Arabia. In addition, a living population sample of 200 subjects was recruited from the same region. The blood metal levels were measured by inductively coupled plasma mass spectrometry (ICP-MS). The calculated means for blood As, $\mathrm{Se}, \mathrm{Ag}, \mathrm{Cd}, \mathrm{Sb}, \mathrm{Hg}$, $\mathrm{Ti}$ and $\mathrm{Pb}$ were 2.7, 10.16, 3.38, 12.06, 1.61, 5.49, 1.33, and $13.5 \mu \mathrm{g} / \mathrm{dl}$ respectively. Blood $\mathrm{Cd}, \mathrm{Hg}$ and $\mathrm{Pb}$ levels were significantly higher in the post-mortem samples compared to the living population with $p$ values $0.001,0.001$ and 0.02 respectively. Moreover, there were statistically significant differences among post-mortem blood $\mathrm{Cd}$ and $\mathrm{Pb}$ levels with regard to post-mortem interval (PMI) which could be attributed to post-mortem redistribution (PMR).
\end{abstract}

Keywords: Post-mortem redistribution; Metals and inductive coupled plasma

\section{Introduction}

Post-mortem assaying of drugs and toxic agents has been there for decades and the accurate interpretation of post-mortem testing results plays a crucial role in the diagnosis of the cause of death [1-3]. The correct interpretation of post-mortem drug analysis could provide vital evidences in the successful prosecution, conviction and subsequent imprisonment of the guilty person, for instance the well-known case of Dr Harold Shipman. Also, the right conclusion about post-mortem levels of xenobiotic is indispensible to avoid executing innocent persons [4-6]. Noteworthy, the databases of necropharmacology have recently grown considerably [7]. For example, Prouty and Anderson listed the concentrations of 69 drugs from different organs and blood vessels from hundreds of autopsied cases died under various conditions [8]. Moreover, Druid and Holmgren reported the femoral concentrations of 83 drugs from thousands of medicolegal autopsies in Swedish laboratories [9]. Furthermore, Schulz et al. compiled a reference table of almost 1000 drugs and xenobiotics from various sources [10].

These comprehensive databases of post-mortem xenobiotic concentrations are considered valuable sources of information that resulted in much better understanding of the mechanisms and predictions of xenobiotics that alter their concentrations after death. Although the database of post-mortem drug concentrations is evergrowing, the available information in the literature about the postmortem metal levels and the possibility of their redistribution after death is scarce.

The metals are a unique class of toxins as they cannot be broken down to non-toxic forms by the biological system. The heavy metals affect multiple organ systems and target biochemical processes and cellular organelles. The heavy metal toxicity usually involves an interaction between free metal ion form and the target site. They become toxic because the human body cannot metabolise, thus they accumulate overtime in the soft tissues, heart, lungs and other body organs until they reach toxic levels. Blood and urinary levels only reflect the amount of element circulating at the time of sampling, which may not relate to the degree of exposure $[11,12]$.

Interestingly, the detection of very high post-mortem blood $\mathrm{Cd}$ level in a single case raised the suspicion of homicide, however further criminal investigation excluded such possibility. Environmental contamination of the biologic specimens and normal post-mortem redistribution of cadmium between tissues were the reasons behind such false allegation [13]. Such cases highlight how the interpretation of the analytical results obtained from autopsy samples represents a real challenge to scientists. Also, they demonstrate the current paucity of information regarding post-mortem metal levels and the possibility of their redistribution after death as an area that need further extensive research.

Thus, in this study we measured the post-mortem whole blood levels of $\mathrm{As}, \mathrm{Se}, \mathrm{Ag}, \mathrm{Cd}, \mathrm{Sb}, \mathrm{Hg}, \mathrm{Ti}$ and $\mathrm{Pb}$ in autopsied cases from

*Corresponding author: Ahmed R Ragab, Department of Forensic Medicine and Clinical Toxicology, Faculty of Medicine, Mansoura University, Egypt, Tel: 00966540990033; E-mail: ahmedrefat1973@yahoo.com

Received December 21, 2016; Accepted July 10, 2017; Published July 17, 2017

Citation: Ragab AR, Al-Mazroua MK, Younis SM, Al- Emam A, Al-Moagel NM et al. (2017) Comparative Study of Blood Metal Levels in Post-Mortem and Living Population Samples from Dammam, KSA. J Forensic Res 8: 385. doi: 10.4172/2157-7145.1000385

Copyright: (c) 2017 Ragab AR, et al. This is an open-access article distributed under the terms of the Creative Commons Attribution License, which permits unrestricted use, distribution, and reproduction in any medium, provided the original author and source are credited. 
Citation: Ragab AR, Al-Mazroua MK, Younis SM, Al- Emam A, Al-Moagel NM, et al. (2017) Comparative Study of Blood Metal Levels in Post-Mortem and Living Population Samples from Dammam, KSA. J Forensic Res 8: 385. doi: 10.4172/2157-7145.1000385

Page 2 of 5

Dammam Forensic Medicine centre in Saudi Arabia and compared the data with the estimated blood levels of the same metals from a living population sample in the same region. Then, we investigated whether the post-mortem interval could have an impact on the measured levels of these metals after death.

\section{Materials and Methods}

\section{Data source and collection}

According to Saudi Arabia regulations, all suspected unnatural deaths (including cases with suspected poisoning, unknown cause of death, unknown identity, or sudden death cases) must be reported to the police by the physician issuing the death certificate. At the institute of Dammam Forensic Medicine, autopsy is always performed in such cases upon request from the police. Peripheral blood, urine, vitreous, gastric content, liver and kidney tissue samples are collected and submitted to the Forensic Chemistry department at Dammam Poison Control Center "DPCC" where all the samples are routinely screened for xenobiotics including metal levels by inductively coupled plasma mass spectrometry (ICP-MS).

This cross-sectional study was conducted in the period between January 2010 and December 2013. During this period, 212 subjects were selected and their official medical examiner records were scrutinized. The circumstances surrounding death, premorbid clinical and demographic information (age, sex, smoking history, nationality, occupation) and co-morbid medical condition were all recorded in order to assess the relationship between post-mortem blood metal levels and the post-mortem interval (period between estimated time of death and time of sample collection). A 10-15 ml sample of peripheral blood-being the most reliable specimen for toxicological testingwas withdrawn from the femoral vein during external examination. Due to lack of equivalent referent population for comparison, a 200 living population sample that undergo pre-employment toxicology screening were enrolled as a control. All the control subjects consented to participate in the study and their demographic data were recorded. Venous blood samples were withdrawn from the antecubital vein with all the necessary precautions to avoid any source of sample contamination.

\section{Analytical methods}

Forensic pathologists instructed technicians on sampling techniques and provided all the necessary equipment. The samples were stored at $4^{\circ} \mathrm{C}$ until transport to the Forensic Chemistry department at DPCC, where the levels of the whole blood As, Se, Ag, Cd, Sb, $\mathrm{Hg}, \mathrm{Ti}$ and $\mathrm{Pb}$ were measured by by ICP-MS. Precisely, $1 \mathrm{ml}$ of each blood sample was transferred to a Teflon digestion tube $(120 \mathrm{ml})$ and mixed up with $7 \mathrm{ml}$ of the acid mixture Nitric/Hydrofluoric/Hydrochloric acids $\left(\mathrm{HNO}_{3} / \mathrm{HF} / \mathrm{HCl}, 4.5: 2: 0.5\right)$ [14]. The tube was sealed and the sample was digested inside a microwave oven (Milestone ETHOS 1600). After digestion, the tubes left to cool down to ambient temperature, Then, the tube was opened and the inside of the lid was rinsed with distilled and de-ionized water (DDW) and the mixture heated on a hot plate $\left(120^{\circ} \mathrm{C}\right)$ for 30 minutes to drive off the residual $\mathrm{HF}$ and $\mathrm{HCl}$. The resulting digest was filtered in a polypropylene flask using $1 \% \mathrm{HNO}_{3}$ and made up to $50 \mathrm{ml}$ volume with DDW. For ICP-MS measurement the clear digest obtained were diluted 10 times using DDW.

Samples and standard reference materials (SRM) were prepared in a batch of six, including a blank $\left(\mathrm{HNO}_{3} / \mathrm{HF} / \mathrm{HCl}\right)$ digest $[10,15]$. The eight different metals ( $\mathrm{As}, \mathrm{Se}, \mathrm{Ag}, \mathrm{Cd}, \mathrm{Sb}, \mathrm{Hg}, \mathrm{Ti}$ and $\mathrm{Pb}$ ) in all the prepared solutions were quantified subsequently by ICP-MS.

\section{Statistical analysis}

Statistical analysis was carried out using SPSS (statistical package for social science) program version 22 (SPSS Inc., Chicago, Illinois, USA) on an IBM compatible computer. Descriptive results were expressed as mean and standard deviation (SD). The student t-test was used to compare the means of blood metal levels between post-mortem samples and the living population control. The postmortem samples were further subdivided into three groups (Group 1: Absence of putrefaction "no evidence of external or internal signs of putrefaction", Group 2: Early degree of putrefaction "evidence of early external or internal signs of putrefaction" and Group 3: "evidence of advanced external or internal signs of putrefaction" Advanced degree of putrefaction) based on the post-mortem interval. The Levene's test was used to test for variance between subgroups of the post-mortem samples and the $\mathrm{p}$ values were considered statistically significant if they were equal or less than $\leq 0.05$.

\section{Results}

This study was conducted on 212 death cases from Dammam Forensic Medicine center over a period of 4 years (between January 2010 and December 2013. They were 191 males (91.1\%) and 21 females (8.9\%) whose ages ranged between 7 and 80 years with a mean of 37.7 year, age distribution is shown.

As regards the nationality, $24.5 \%$ of the studied cases were Saudi $(n=52)$ whereas, the remaining $75.5 \%$ were non-Saudi $(n=160)$. With reference to the occupation of the studied cases, both farmers $(n=30)$ and mechanical workers $(n=30)$ were equally represented ( $14.2 \%$ each). Also, the majority $(86.3 \%)$ of the studied cases were non-smokers $(n=183)$. The three most prominent causes of death were hanging $(\mathrm{n}=71 ; 33.4 \%)$, sudden natural death $(\mathrm{n}=39 ; 18.4 \%)$ and cut throat $(n=23 ; 10.8 \%)$. The other causes of death were falling from height, stab wound, drowning, drug overdose and electrocution whereas in $11.5 \%$ of cases $(n=24)$ the causes of death were undetermined, as shown in Table 1. With reference to the place of death, it was indoors in $44.3 \%$ of the studied cases $(n=94)$ whereas in $35.45 \%$ of cases $(n=75)$, death was outdoors. Also, $14.20 \%$ died in medical facility and $6.10 \%$ died from drowning. In more than half of the studied cases putrefaction did not start ( $\mathrm{n}=135,63.7 \%)$, whereas, 55 cases were in a state of early putrefaction $(25.9 \%)$ and the remaining 22 cases were in a state of advanced putrefaction (10.4\%), as shown in Table 1.

As regards the two hundreds living population samples, they were all males. More than half of them were Non-Saudi ( $n=116 ; 58 \%)$ whereas, the other $42 \%$ were Saudi $(n=84)$. The majority of them were non-smoker ( $\mathrm{n}=176 ; 88 \%)$, as shown in Table 2 .

As regards the measured blood metal levels in this study, as shown in Table 3; firstly the mean post-mortem blood $\mathrm{Cd}, \mathrm{Hg}$ and $\mathrm{Pb}$ levels were statistically significant higher (with mean \pm SD of $12.06 \pm 4.62$, $5.49 \pm 3.25$ and $13.50 \pm 3.39 \mu \mathrm{g} / \mathrm{dl}$ respectively) than their calculated means in the living population samples (with mean \pm SD of $0.10 \pm 0.07$, $1.75 \pm 1.12$ and $7.01 \pm 2.39$.

Secondly, the mean post-mortem blood Se and Sb levels were statistically significant lower (with mean \pm SD of $10.1 \pm 6.03$ and 1.61 $\pm 1.92 \mu \mathrm{g} / \mathrm{dl}$ respectively) than their calculated means in the living population samples (with mean \pm SD of $18.95 \pm 8.38$ and $2.82 \pm 2.03$ $\mu \mathrm{g} / \mathrm{dl}$ respectively) $\mathrm{p}$ values: 0.001 . However, there were not statistically significant differences of the blood As and Ti levels between the postmortem and the living population samples.

Levene's test revealed a significant increase in post-mortem blood 
Citation: Ragab AR, Al-Mazroua MK, Younis SM, Al- Emam A, Al-Moagel NM, et al. (2017) Comparative Study of Blood Metal Levels in Post-Mortem and Living Population Samples from Dammam, KSA. J Forensic Res 8: 385. doi: 10.4172/2157-7145.1000385

Page 3 of 5

\begin{tabular}{|c|c|c|c|c|c|c|c|}
\hline \multirow[t]{3}{*}{ Metal } & \multirow{2}{*}{\multicolumn{2}{|c|}{$\begin{array}{l}\text { Group } 1 \\
(n=135)\end{array}$}} & \multirow{2}{*}{\multicolumn{2}{|c|}{$\begin{array}{c}\text { Group } 2 \\
(\mathrm{n}=55)\end{array}$}} & \multirow{2}{*}{\multicolumn{2}{|c|}{$\begin{array}{c}\text { Group } 3 \\
(n=22)\end{array}$}} & \multirow{3}{*}{$\begin{array}{c}\text { Levene's test } \\
p \text { Value }\end{array}$} \\
\hline & & & & & & & \\
\hline & Mean & $\pm \mathrm{SD}$ & Mean & $\pm \mathrm{SD}$ & Mean & $\pm \mathrm{SD}$ & \\
\hline \multirow[t]{3}{*}{ As } & \multirow[t]{3}{*}{2.65} & \multirow[t]{3}{*}{3.3} & \multirow[t]{3}{*}{3.14} & \multirow[t]{3}{*}{5.29} & \multirow[t]{3}{*}{2.14} & \multirow[t]{3}{*}{1.75} & Gp 1 and 2: $P=0.34$ \\
\hline & & & & & & & Gp 1 and $3: P=0.38$ \\
\hline & & & & & & & Gp 2 and $3: P=0.35$ \\
\hline \multirow[t]{3}{*}{$\mathrm{Se}$} & \multirow[t]{3}{*}{10.54} & \multirow[t]{3}{*}{6.21} & \multirow[t]{3}{*}{10.61} & \multirow[t]{3}{*}{5.47} & \multirow[t]{3}{*}{10.34} & \multirow[t]{3}{*}{4.07} & Gp 1 and $2: P=0.23$ \\
\hline & & & & & & & Gp 1 and $3: P=0.44$ \\
\hline & & & & & & & Gp 2 and $3: P=0.23$ \\
\hline \multirow[t]{3}{*}{$\mathrm{Ag}$} & \multirow[t]{3}{*}{3.54} & \multirow[t]{3}{*}{1.14} & \multirow[t]{3}{*}{3.48} & \multirow[t]{3}{*}{1.12} & \multirow[t]{3}{*}{3.42} & \multirow[t]{3}{*}{0.87} & Gp 1 and 2: $P=0.77$ \\
\hline & & & & & & & Gp 1 and 3: $P=0.64$ \\
\hline & & & & & & & Gp 2 and 3: $P=0.23$ \\
\hline \multirow[t]{3}{*}{$\mathrm{Cd}$} & \multirow[t]{3}{*}{12.27} & \multirow[t]{3}{*}{3.75} & \multirow[t]{3}{*}{9.39} & \multirow[t]{3}{*}{3.47} & \multirow[t]{3}{*}{24} & 3.39 & Gp 1 and 2: $P=0.10$ \\
\hline & & & & & & & Gp 1 and $3: P=0.04^{*}$ \\
\hline & & & & & & & Gp 2 and $3: P=0.03^{*}$ \\
\hline $\mathrm{Sb}$ & 1.6 & 1.94 & 1.81 & 1.94 & 1.55 & 1.38 & Gp 1 and 2: $P=0.26$ \\
\hline & & & & & & & Gp 1 and $3: P=0.28$ \\
\hline & & & & & & & Gp 2 and $3: P=0.26$ \\
\hline $\mathrm{Hg}$ & 5.89 & 3.24 & 5.1 & 2.06 & 5.28 & 1.79 & Gp 1 and 2: $P=0.78$ \\
\hline & & & & & & & Gp 1 and $3: P=0.28$ \\
\hline & & & & & & & Gp 2 and $3: P=0.78$ \\
\hline $\mathrm{Ti}$ & 1.25 & 1.24 & 1.41 & 1.19 & 2.15 & 5.24 & Gp 1 and 2: $P=0.50$ \\
\hline & & & & & & & Gp 1 and 3: $P=0.30$ \\
\hline & & & & & & & Gp 2 and 3: $P=0.40$ \\
\hline $\mathrm{Pb}$ & 12.66 & 2.77 & 13.87 & 2.44 & 24.55 & 7.88 & Gp 1 and 2: $P=0.10$ \\
\hline & & & & & & & Gp 1 and $3: P=0.01^{*}$ \\
\hline & & & & & & & Gp 2 and $3: P=0.02^{*}$ \\
\hline
\end{tabular}

Table 1: Blood metal levels at variable post-mortem intervals.

\begin{tabular}{|c|c|c|c|}
\hline \multicolumn{4}{|c|}{ Post-mortem Cases } \\
\hline \multicolumn{4}{|c|}{ Total number of cases: 212} \\
\hline \multicolumn{2}{|l|}{ Year distribution } & \multicolumn{2}{|c|}{ Nationality } \\
\hline 2010:00:00 & 6 & Saudi & $52(24.5 \%)$ \\
\hline 2011:00:00 & 42 & Non-Saudi & $160(75.5 \%)$ \\
\hline 2012:00:00 & 79 & \multicolumn{2}{|c|}{ Gender Distribution } \\
\hline 2013:00:00 & 85 & Male & $191(90.1 \%)$ \\
\hline- & - & Female & $21(9.9 \%)$ \\
\hline \multicolumn{2}{|l|}{ Age Groups } & \multicolumn{2}{|c|}{ Occupation } \\
\hline Gp1: $<10$ years & $01(0.5 \%)$ & Mechanical- worker & $30(14.2 \%)$ \\
\hline Gp2: $10-19$ years & $04(1.9 \%)$ & Farmer & $30(14.2 \%)$ \\
\hline Gp3: $20-29$ years & $66(31.1 \%)$ & Un-detected & $152(71.6 \%)$ \\
\hline Gp4: $30-39$ years & $56(26.4 \%)$ & - & - \\
\hline Gp5: $40-49$ years & $44(20.8 \%)$ & - & - \\
\hline Gp6: $50-59$ years & $35(16.5 \%)$ & - & - \\
\hline Gp7: 60-69 years & $04(1.9 \%)$ & \multicolumn{2}{|c|}{ Smoking Habit } \\
\hline Gp8:>70 years & $02(0.9 \%$ & Non-Smoker & $183(86.3 \%)$ \\
\hline \multicolumn{2}{|c|}{ Mean \pm SD (Min.-Max.) $\mu \mathrm{g} / \mathrm{dl}$ (37.7 years) (7-80 years) } & Smoker & $29(13.7 \%)$ \\
\hline \multicolumn{2}{|c|}{ Place of Death } & \multicolumn{2}{|c|}{ Postmortem Changes } \\
\hline Indoor & $94(44.3 \%)$ & Absence of putrefaction & $135(63.7 \%)$ \\
\hline Outdoor & $75(35.4 \%)$ & Early degree of putrefaction & $55(25.9 \%)$ \\
\hline In medical facility & $30(14.2 \%)$ & $\begin{array}{l}\text { Advanced degree of } \\
\text { putrefaction }\end{array}$ & $22(10.4 \%)$ \\
\hline Under water & $13(6.1 \%)$ & & \\
\hline \multicolumn{4}{|l|}{ Cause of Death } \\
\hline Hanging & $71(33.4 \%)$ & Drowning & $10(4.7 \%)$ \\
\hline Sudden Death & $39(18.4 \%)$ & $\begin{array}{l}\text { Poisoning and drug } \\
\text { overdose }\end{array}$ & $09(4.2 \%)$ \\
\hline Cutthroat & $23(10.8 \%)$ & Electracaution & $08(3.8 \%$ \\
\hline Falling from a height & $14(6.0 \%)$ & Undetermined & $24(11.5 \%)$ \\
\hline Stab wound & $14(6.0 \%)$ & & \\
\hline
\end{tabular}

Table 2: Demographic data of the studied population (age, gender, nationality and smoking habit). 


\begin{tabular}{|c|c|c|c|c|c|c|c|}
\hline \multirow[t]{3}{*}{ Metal } & \multirow{2}{*}{\multicolumn{2}{|c|}{$\begin{array}{c}\text { Post-mortem } \\
\quad(n=212)\end{array}$}} & \multirow{2}{*}{\multicolumn{2}{|c|}{$\begin{array}{l}\text { Living } \\
(n=200)\end{array}$}} & \multirow{2}{*}{\multicolumn{2}{|c|}{ t-test }} & \multirow[t]{3}{*}{ LOD* } \\
\hline & & & & & & & \\
\hline & Mean & $\pm S D$ & Mean & $\pm S D$ & $t$ & $\mathrm{p}$ & \\
\hline As & 2.7 & 1.73 & 2.37 & 1.47 & 1.11 & 0.29 & $<$ LOD-35.80 \\
\hline Se & 10.16 & 6.03 & 18.95 & 8.38 & 12.27 & $0.001^{*}$ & $<$ LOD-54.00 \\
\hline $\mathrm{Ag}$ & 3.38 & 1.29 & 3.78 & 7.07 & 0.8 & 0.43 & $<$ LOD-10.00 \\
\hline $\mathrm{Cd}$ & 12.06 & 4.62 & 0.1 & 0.07 & 6.16 & $0.001^{*}$ & $<$ LOD-295.50 \\
\hline $\mathrm{Sb}$ & 1.61 & 1.92 & 2.82 & 2.03 & 13.23 & $0.001^{*}$ & $<$ LOD-9.10 \\
\hline $\mathrm{Hg}$ & 5.49 & 3.25 & 1.75 & 1.12 & 5.01 & $0.001^{*}$ & $<$ LOD-24.40 \\
\hline $\mathrm{Ti}$ & 1.33 & 1.98 & 1.07 & 0.94 & 1.67 & 0.09 & $<$ LOD-24.00 \\
\hline $\mathrm{Pb}$ & 13.5 & 3.39 & 7.01 & 2.39 & 2.42 & $0.02^{*}$ & $<$ LOD-214.00 \\
\hline
\end{tabular}

Table 3: Comparison between blood metal levels of both the post-mortem and living population samples.

Cd levels with advancing putrefaction. The post-mortem blood Cd levels were significantly higher in the group with advanced putrefaction (with mean \pm SD of $24.00 \pm 2.39$ ) in comparison with the other two groups: absence of putrefaction (with mean \pm SD of $12.27 \pm 3.75$ ) and early putrefaction (with mean \pm SD of $9.39 \pm 30.47$ ), with p values: 0.04 and 0.03 respectively, as shown in Table 3. Moreover, the post-mortem blood $\mathrm{Pb}$ levels were significantly higher in the group with advanced putrefaction (with mean \pm SD of $24.55 \pm 7.88$ ) in comparison with the other two groups: absence of putrefaction (with mean \pm SD of $12.66 \pm$ 2.77 ) and early putrefaction (with mean \pm SD of $13.87 \pm 2.44$ ), with $p$ values: 0.01 and 0.02 respectively, as shown in Table 3 . However, there were no statistically significant differences between the post-mortem blood levels of $\mathrm{As}, \mathrm{Se}, \mathrm{Ag}, \mathrm{Sb}, \mathrm{Hg}$ and $\mathrm{Ti}$ among the three groups, as shown in Table 3.

\section{Discussion}

Post-mortem toxicological analysis has become as important as histopathology for the diagnosis of the cause of death. However, Postmortem changes, such as post-mortem diffusion and redistribution, make the interpretation of xenobiotic concentrations measured in post-mortem samples difficult or impossible. Moreover, postmortem xenobiotic concentrations unpredictably change with the site and time of sampling, as a result of the phenomenon of postmortem redistribution [16-20]. The phenomenon of post-mortem redistribution was coined by Pounder and Jones [21]. Since then, the studies investigating drugs redistribution after death are ever-growing; however, very little studies discussed the post-mortem redistribution possibility of heavy metals and whether a true relationship between lethal events and the post-mortem tissues and blood metal levels does exist, because of the lack of such comprehensive studies, tabulations of 'fatal concentrations' could be misleading and the post-mortem measurements must be interpreted with extreme caution [21].

In the present study, the post-mortem blood Cd level was significantly higher than its level in the living population sample, as shown in Table 2. Moreover, the post-mortem blood Cd levels were significantly higher in the group with advanced putrefaction compared to the other two groups (absence of putrefaction and early putrefaction with p values: 0.04 and 0.03 respectively, as shown in Table 3 . In some cases, the post-mortem blood $\mathrm{Cd}$ reached levels incompatible with life. In such cases, the medical examiner reports were re-examined to trace back any evidence of pre-mortem clinical toxicities. In addition, all the precautions were undertaken during sample collection to avoid any source of blood contamination. Therefore, the suspicion of cadmium toxicity was excluded and the only plausible explanation for such thousand-fold elevation of post-mortem Cd level is post-mortem redistribution from the surrounding tissue and organs. In agreement with our finding, a previous study measured $\mathrm{Cd}, \mathrm{Zn}, \mathrm{Cu}$, and $\mathrm{Fe}$ in blood and post-mortem tissue (both fresh and formalin fixed) samples. This study revealed that the post-mortem blood Cd level was hundredfold higher than its pre-mortem level and did not indicate ante-mortem exposure to $\mathrm{Cd}$. This elevated post-mortem Cd level was attributed to the very rapid elution of Cd from body organs [22].

Also, our results were consistent with Schier et al., 2010 who reported the same finding [13]. It is well documented that most drugs and toxic agents undergo post-mortem redistribution, particularly drugs in cardiac blood is affected by post-mortem redistribution from surrounding tissue (e.g., lung, gastrointestinal tract, and myocardium) $[23,24]$. Moreover, drugs excreted in the liver may be redistributed via the hepatic veins to inferior vena cava, right cardiac chamber, and pulmonary vessels [19]. The same principle apply to metals; Cd accumulates in very high concentrations in various body tissues (especially liver and kidney) during life $[23,25,26]$. However, inequitable distribution of red blood cells due to clotting or hypostasis cannot explain increased post-mortem whole blood Cd level [7]. Thus, post-mortem redistribution is the likely explanation for the significant increase of post-mortem blood $\mathrm{Cd}$ in cases with advanced putrefaction compared to those with no/early putrefaction.

Noteworthy, we found that blood $\mathrm{Hg}$ and $\mathrm{Pb}$ levels were statistically significant higher in the post-mortem cases compared with the living population samples, with $\mathrm{p}$ values of 0.001 , as shown in Table 2 . Moreover, the post-mortem blood $\mathrm{Pb}$ levels were significantly higher in the group with advanced putrefaction compared to the other two group (absence of putrefaction and early putrefaction), with $\mathrm{p}$ values: 0.01 and 0.02 respectively, as shown in Table 3 . This elevation of postmortem blood $\mathrm{Pb}$ levels could be attributed to the aforementioned phenomenon of post-mortem redistribution. However, there were no statistically significant differences between the post-mortem blood levels of $\mathrm{As}, \mathrm{Se}, \mathrm{Ag}, \mathrm{Sb}, \mathrm{Hg}$ and $\mathrm{Ti}$ among the three groups.

Interestingly, we found that blood Se and Sb levels were statistically significant lower in the post-mortem cases compared with the living population samples, with $\mathrm{p}$ values of 0.001 , as shown in Table 2 . However, there were not statistically significant differences of the blood As and Ti levels between the post-mortem and the living population samples, as shown in Table 2. The finding of low post-mortem blood Se and $\mathrm{Sb}$ levels might be attributed to back diffusion or redistribution of these two metals from blood to the surrounding tissues.

The authors used living population samples as control for comparison in this study due to the lack of pre-mortem blood samples and absence of established reference ranges for the studied population in the literature. Although, it is not optimal, our results of the living population samples could be used as reference ranges for comparison in future studies in the region.

\section{Conclusion}

In the present study, we showed that post-mortem blood Cd and $\mathrm{Pb}$ levels were significantly higher than the measured values in the living population samples and their levels increased with post-mortem interval. These variations in post-mortem levels are most probably due to post-mortem diffusion and redistribution. The researchers also found that post-mortem blood levels of both Se and Sb were significantly different from the measured reference range of the living population sample studied. Indeed, experimental research is needed to further investigate the post-mortem redistribution of metals for accurate interpretation of post-mortem analysis results. 
Citation: Ragab AR, Al-Mazroua MK, Younis SM, Al- Emam A, Al-Moagel NM, et al. (2017) Comparative Study of Blood Metal Levels in Post-Mortem and Living Population Samples from Dammam, KSA. J Forensic Res 8: 385. doi: 10.4172/2157-7145.1000385

Page 5 of 5

\section{Conflict of Interests}

The authors declare that they have no competing interests.

\section{Funding}

Non-funded work.

\section{References}

1. Wharton JC (2010) The arsenic century: How victorian britain was poisoned at home, work and play. Oxford university press inc, New York

2. Brown L, Stewart CG, Trial of Dr Pritchard In, Brown L, Stewart GG, et al. (1883) Trials of murder by poisoning London: Stevens and Sons119. Chancery lane law publishers and booksellers: 397-448.

3. Mc Bay J (1973) Toxicological findings in fatal poisonings. Clin Chem 19: 361-365.

4. Leiken JB, Watson WA (2003) Post-mortem toxicology: What the dead can and cannot tell us. J Toxicol Clin Toxicol 41: 47-56.

5. Pounder DJ (2003) The case of Dr Shipman. Am J Forensic Med Pathol 24: 219-226.

6. Drummer O, Forrest ARW, Goldberger B, Karch SB (2004) Forensic science in the dock. BMJ 329: 636-637.

7. Kennedy MC (2010) Postmortem drug concentrations. Intern Med J 40: 183-187.

8. Prouty RW, Anderson WH (1990) The forensic science implications of site and temporal influences on post-mortem blood drug concentrations. J Forensic Sci 35: $243-270$

9. Druid H, Holmgren $\mathrm{P}$ (1997) A compilation of fatal and control concentrations of drugs in post mortem femoral blood. J Forensic Sci 42: 79-87.

10. Schulz M, Iweresen-Bergmann S, Andresen H, Schmoldt A (2012) Therapeutic and toxic blood concentrations of nearly 1000 drugs and other xenobiotics. Crit Care 16: R136

11. Ogola JG, Mitullah WV, Omulo MA (2002) Impact of the gold mining on the environment and human health: A case study in migori gold belt, Kenya. Environ Geochem Health 24: 141-157.

12. Pinheiro MCN, Crespo-Lopez ME, Vieira JLF, Oikawa T, Guimaraes GA, et al. (2007) Mercury pollution and childhood in amazon riverside villages. Environ Int 33: 56-51.
13. Schier JG, Heninger M, Wolkin A, Kieszak S, Caldwell KL, et al (2010) Postmortem blood cadmium, lead, and mercury concentrations: Comparisons with regard to sampling location and reference ranges for living persons. J Anal Toxicol 34: 129-34.

14. Date AR, Gray AL (1989) Applications of inductively coupled plasma mass spectrometry. Chapman and hall, New York.

15. Bolann BJ, Rahil-Khazen R, Henriksen H, Isrenn R, Ulvik RJ (2007) Evaluation of methods for trace-element determination with emphasis on their usability in the clinical routine laboratory. Scand J Clin Lab Invest 67: 353-366.

16. Bentur Y, Tsipiniuk A, Taitelman U (1999) Postmortem digoxin-like immunoreactive substances (DLIS) in patients not treated with digoxin. Hum Exp Toxicol 18: 67-70.

17. Hilberg T, Rogde S, Morland J (1999) Postmortem drug redistribution-human cases related to results in experimental animals. J Forensic Sci 44: 3-9.

18. Battah AH, Hadidi KH (1998) Stability of trihexyphenidyl in stored blood and urine specimens. Int J Legal Med 111: 111-114.

19. Pelissier-Alicot AL, Gaulier JM, Champsaur P, Marquet P (2003) Mechanisms underlying postmortem redistribution of drugs: A review J Anal Toxicol 27: 533-544

20. Ferner RE (2008) Post-mortem clinical pharmacology. Br J Clin Pharmacol 66 430-443.

21. Pounder DJ, Jones GR (1990) Post-mortem drug redistribution-a toxicological nightmare. Forensic Sci Int 45: 253-263.

22. Koizumi N, Hatayama F, Sumino K (1994) Problems in the analysis of cadmium in autopsied tissues. Environ Res 64: 192-198.

23. Yarema MC, Becker CE (2005) Key concepts in postmortem drug redistribution. Clin Toxicol (Phila) 43: 235-241.

24. Moriya F, Hashimoto $Y$ (1999) Redistribution of basic drugs into cardiac blood from surrounding tissues during early stages postmortem. J Forensic Sci 44 $10-16$

25. Baselt RC (2002) Disposition of toxic drugs and chemicals in man, $6^{\text {th }}$ ed Biomedical publications, Foster City, CA.

26. Lauwerys RR, Hoet $P$ (2001) Industrial chemical exposure: guide- lines for biological monitoring, $3^{\text {rd }}$ ed. Lewis publishers, New York.
Citation: Ragab AR, Al-Mazroua MK, Younis SM, Al- Emam A, Al-Moagel NM et al. (2017) Comparative Study of Blood Metal Levels in Post-Mortem and Living Population Samples from Dammam, KSA. J Forensic Res 8: 385. doi: 10.4172/2157-7145.1000385
OMICS International: Open Access Publication Benefits \& Features

Unique features:

- Increased global visibility of articles through worldwide distribution and indexing

- Showcasing recent research output in a timely and updated manner

Special issues on the current trends of scientific research

Special features:

- $700+$ Open Access Journals

$50,000+$ editorial team

Rapid review process

- Quality and quick editorial, review and publication processing

- Indexing at PubMed (partial), Scopus, EBSCO, Index Copernicus and Google Scholar etc

- Sharing Option: Social Networking Enabled

- Authors, Reviewers and Editors rewarded with online Scientific Credits

- Befter discount for your subsequent articles

Submit your manuscript at: www.omicsonline.org/submission/ 